\title{
OZONE DEPLETING SUBSTANCES ELIMINATION MANAGEMENT: THE SUCCESS STORY OF MACEDONIA
}

PhD Margarita Matlievska, Assistant Professor, Faculty of Economics, Goce Delcev University - Stip, Macedonia, e-mail: margarita.matlievska@ugd.edu.mk

\begin{abstract}
Man, with its activities, produces and uses substances that have negative impact on the environment and the human health, and can cause an economic damage. Consequently, they have a great impact on quality of life. Among the most harmful chemicals are Ozone Depleting Substances that are subject of regulation with international conventions. This Paper supports the fact that each country has to undertake national efforts for ozone depleting substances reduction and elimination. In that respect, the general objective of the Paper is to present the Macedonian unique experience regarding its efforts to reduce or eliminate these substances. The following two aspects were subject to the research: national legislation which regulates the Ozone Depleting Substances import and export as well as the implementation of the projects that resulted with the elimination of Ozone Depleting Substances quantities in the period $1995-2010$. The research outcomes confirm the starting research hypothesis i.e. that with adequately created and implemented national action, the amount of Ozone Depleting Substances consumption can dramatically fall.
\end{abstract}

Key words: Montreal Protocol, Vienna Convention, Ozone Unit, Macedonia, Phase-out.

\section{Introduction}

It is difficult to define the term quality of life, but everyone can agree that it incorporates the meaning of the term good life. However envisaged, the good life has always been a demanding goal (Prescott-Allen, R., 2001). Generally, quality of life refers to the individual and society well-being. It is a complex, multifaceted construct that requires multiple approaches from different theoretical angles (E. Diener and E. Suh, 1997). Furthermore, in order to measure it, it requires quantification. And here is the problem: how to choose appropriate quantitative indicators that can measure quality of life? One of the answers can be by putting a symbol of equitation between the quality of life and pursuing to obtain sustainable development; now, the things can seem simpler.

Speaking about the sustainable development indicators, the major work on theirs development belongs to United Nations. Namely, the Commission on Sustainable Development (CSD) in 1995 approved the Programme of Work on Indicators of Sustainable Development that result with a report. This report presents, inter alia, the core set of indicators to measure progress toward sustainable development clustered as economic, social, environmental and institutional. They present the state in different "themes". For example, environmental themes are atmosphere, land, fresh water, biodiversity, etc. Atmospheric issues that have priority, by reason of theirs impacts on human health and economic damage for example, include among others, stratospheric ozone depletion and tropospheric ozone levels. Many of the effects are global, long-term, and irreversible with consequences for future generations. One of the three indicators related to the atmosphere included in the CSD core set is consumption of ozone depleting substances (ODS) ${ }^{1}$. It assesses ODS phaseout (subject to the Montreal Protocol and its subsequent amendments) and presents one of the indicators for measuring the quality of life.

\section{Snapshot on Ozone Depleting Substances elimination policy beginnings}

The ozone layer is a shield from the harmful effect of the ultraviolet rays emitted from the Sun, which reaching the

\footnotetext{
${ }^{1}$ Other two are emissions of greenhouse gases and ambient concentration of air pollutants in urban areas.
} 
surface of the Earth contribute for the global warming, disturbing the chain of food in the seas, decreasing the harvest incomes, causing skin cancer to people and animals, suppression of the immunological system and other. The first "ozone hole" is discovered over the Antarctic in 1985. This scientifically confirmed the postulate of Sherwood Rowland and Mario Molina (Molina M, Rowland S, 1974) that the chloral and brome carbohydrates deteriorate the ozone layer ${ }^{2}$. The most often used substances responsible for $80 \%$ of the total depletion of the stratospheric ozone layer are chlorofluorocarbons (CFCs) that are used in the cooling and airconditioning devices, or foam sprayers, solvents, sterilants and aerosol propellants. ${ }^{3}$ Besides CFCs, there are other substances depleting the ozone layer, such as halons, methylbromide, hydro chlorofluorocarbons (HCFCs) and other highly reactive chemicals that have harmful influence on the ozone layer.

Due to the increased danger from enlargement of the "ozone hole" warned by the scientific public, it became clear that there has to be adopted a document on a global level contributing to the undertaking measures for decreasing i.e. excluding this danger. The Vienna Convention for Protection of the Ozone Layer form 1985 is a framework document that gives the directives of the international action in this segment of the protection of the environment and people's health. Since the Conference's provisions do not define limitations and recommendations, two years later, on 16 September 1987, in Montreal, the International community,

\footnotetext{
2 The ozone is a molecule composed of three oxygen atoms. It is concentrated in the upper layers of the atmosphere between the $20^{\text {th }}$ and $40^{\text {th }}$ kilometer above the surface of the Earth. Around 3 molecules of ozone are found in 10 million molecules of air.

3 When they are released into the atmosphere, under the influence of the sun's rays, these halogenated hydrocarbons decompose freeing chlorine atoms that enter into reaction with the ozone molecule, thus deplete the ozone layer.
}

under the aegis of United Nation Environment Programme (UNEP) accepted a Protocol with concrete measures for import control and consumption of Ozone Depleting Substances (ODS). The Montreal Protocol précised even more the Convention and predicts concrete quantified obligations in order to limit or eliminate the ODS. Furthermore, it determines deadlines for implementation of measures and activities for decreasing and removal of these substances. The Protocol specifies an obligation for complete elimination of the HCFC's until 2030. It stipulates a range of activities for international collaboration, such as concrete procedures and production regime standards, packing, storage, new loading, transport, usage, as well as procedures in the international turnover with these substances. Further on, procedures are anticipated in order to increase caution when managing these substances, decrease their consumption, education and public awareness rising for the need of ozone layer protection and the loss that ODS can cause. The Protocol also envisages sanctions for the countries violating the Protocol's provisions, mostly in a form of reducing the financial support.

There is no doubt that the Montreal Protocol on Substances that Deplete the Ozone Layer set the foundations of the global action for reduction, substitution and complete elimination of these chemicals. However, soon it became clear that the Montreal Protocol will not provide adequate protection of the ozone layer. Therefore, in 1990 in London, by amending the Protocol, a financial mechanism for fulfillment the document's obligations was set up. Multilateral Fund was established in order to implement the Montreal Protocol and its basic goal is to provide a financial help for developing countries or countries with economy in transition through donations in order to prepare and implement projects for ozone 
layer protection. ${ }^{4}$ International cooperation under the Vienna Convention, the Montreal Protocol, and subsequent amendments has resulted in a significant decrease in global production and consumption of the major ozone-depleting substances. ${ }^{5}$ Nevertheless, due to the long life times of these substances in the atmosphere, complete recovery of the ozone layer is not expected until $2050 .^{6}$

In the European Union, in 2009 the European Parliament and the Council adopt a new Regulation (EC) 1005/2009 ${ }^{7}$ in the area of ODS management and control. Its main goal is ODS emissions reduction by inhibit their production, import, export, selling and almost all ODS usage, with small exceptions. The Regulation provides adequate and accelerated implementation of the Montreal Protocol.

\section{National legislative overview}

Republic of Macedonia has ratified the Vienna Convention for Protection of the Ozone Layer on 10 March $1994^{8}$ and the Montreal Protocol for Substances that

\footnotetext{
${ }^{4}$ Later, in the period from 1992 to 1999 were adopted three more changes and amendments of the Montreal Protocol (Amendmends from Copenhagen - 1992, from Montreal - 1997, from Beijing - 1999). Basic reason for adopting the amendments and their acceptance is to perceive the real situation with the depleting ozone layer and the need of an accelerated and aggressive action for elimination of the ozone depleting substances.

5 United Nations Economic and Social Council, Protection of the Atmosphere, Addendum, Report of the Secretary-General, Commission on Sustainable Development, Fourth Session, 18 April-3 May, 1996.

6 European Environment Agency, Environmental Signals 2000, Environmental Assessment Report No. 6, 2000.

${ }^{7}$ Refers to the Regulation (EC) n. 1005/2009 of the European Parliament and Council from 16 September 2009 for ozone layer depleting substances.

${ }^{8}$ SFR Yugoslavia ratified it by Law on ratification published in "Official Gazette of SFRY" n.1/1990.
}

Deplete the Ozone Layer ${ }^{9}$. Macedonia also ratified the amendments to the Montreal Protocol from London ${ }^{10}$, Copenhagen ${ }^{11}$, Montreal $^{12}$ and Beijing ${ }^{13}$.

Institutionally, the Ministry for Environment and Physical Planning (MOEPP) has legal obligation to create the policy of the country in the area of the environment. According to the existing legislation, the MOEPP is responsible for monitoring the state of environment and it conducts the affairs related to protection of water, soil, flora, fauna, air and the ozone layer against pollution, etc.

Macedonia belongs in the group of countries classified in the Article $5^{14}$ of the Montreal Protocol. Macedonia is not a HCFC's producer, but consumer in the service sector.

In Macedonia, the first steps for implementation of the national action for ozone layer protection begun in 1996 by elaborating the National program for elimination of ozone layer depleting substances. ${ }^{15}$ This document gives an excellent base for implementing a successful process for elimination of ODS.

\footnotetext{
9 SFR Yugoslavia ratified it by the Law on ratification published in "Official Gazette of SFRY" n. 16/90.

10 Republic of Macedonia, with The Law on ratification ("Official Gazette of RM 25/98) ratifies the Protocol.

11 Republic of Macedonia, with The Law on ratification ("Official Gazette of RM 25/98) ratifies the Protocol.

12 Republic of Macedonia, with The Law on ratification ("Official Gazette of RM 51/99) ratifies the Protocol.

13 Republic of Macedonia, with The Law on ratification ("Official Gazette of RM 13/2002) ratifies the Protocol.

${ }^{14}$ Article 5 refers to developing countries, members of the Montreal Protocol, with an annual level of consumption less than 0,3 kilograms per capita of the controlled substances from Anex A and less than 0,2 kilograms per capita of the controlled substances from Anex V. For these countries, for most of the substances, there is a permitted grace period of 10 years comparing to the developed countries.

${ }^{15}$ The Program is approved on the $20^{\text {th }}$ meeting of the Executive Committee of the Multilateral Fund, held in the middle of October 1996 in Montreal.
} 
The coordinator role of the activities for realization of the National program has been appointed to the Office for Protection of the Ozone Layer (Ozone Unit) of the MOEPP $^{16}$. The Office monitors the ODS consumption and has an active role in the procedure of issuing ODS import/export permits. This facilitates the control of ODS internal and external trade.

In order to limit and eliminate the ODS and the ODS containing devices, a number of by-laws were adopted with the following dynamic:

- From $1^{\text {st }}$ March 1997, import of ODS can only be performed with a permit issued by the MOEPP.

- From 12 June 1998, used devices containing ODS (fridges, refrigerators, cooling devices, heat pumps, etc.) can only be imported with a permit issued by the MOEPP.

- In December 2004, the MOEPP prepared a Manual on detailed conditions required for permit issuance of imported/exported goods that have mark $\mathrm{D} 4^{17}$. The Manual clearly indicates the documents, information and data that should be provided during the import/export of ODS or ODS containing devices.

- In 2006, a Directive on banning the ODS import and the import of used fridges, refrigerators and other devices for

\footnotetext{
16 On $1^{\text {st }}$ February 1997, the Office for Ozone Layer Protection was established as an unit in the frames of the MOEPP. The Office coordinates the activities for providing financial and technical assistance of the enterprises, monitors the ODS consumption, import and export, participates in the preparation of legal acts and administrative measures connected with the ODS replacement/substitution, implements vast information program for public awareness raising concerning the importance of ozone layer protection and represents a liaison between the government agencies involved in the process for ODS substitution.

${ }^{17}$ D4 goods can be imported/exported only with issued permit from the MOEPP (Decision for the form of procedures during import and export of goods, Official Gazette of Republic of Macedonia number 91/2004).
}

cooling and freezing, was adopted ("Official Gazette of the Republic of Macedonia", No. 87/2006). According to this Directive, it is banned to import already used fridges, refrigerators or other devices for cooling and freezing which contain substances from Anex A group I of the Montreal Protocol starting from $1^{\text {st }}$ of January 2007. Import of substances from Anex A group I of the Montreal Protocol is interdicted from $1^{\text {st }}$ of January 2009.

- From $1^{\text {st }}$ of January 2008, new devices containing ODS (fridges, refrigerators, cooling devices, heat pumps etc.) can only be imported with a permit issued by the MOEPP.

- In 2010, the Directive on banning the ODS production and trade, as well as production and trade of products which contain ODS, was adopted ("Official Gazette of Republic of Macedonia" $n$. 92/2010).

- In 2010, the Directive on banning the import and export of products which contain HCFC's, was adopted. (“Official Gazette of Republic of Macedonia" $n$. 92/2010).

- In 2010, the Directive on limiting the ODS import was adopted. ("Official Gazette of Republic of Macedonia" n.92/2010).

- In 2010, the Directive on limiting the import of devices for air-conditioning containing HCFC's was adopted. ("Official Gazette of Republic of Macedonia" n.92/2010).

- The above-mentioned regulations assure limitation, control and evidence of the imported amounts of stratospheric ozone layer depleting substances. In order to have an inventory of the annual import and the consumption of these chemicals, the Ozone Unit prepared a data base that provides a clear picture with the ODS in the country.

The regulation (EC) 1005/2009 transposition is mainly completed with the above-mentioned regulations. 


\section{National projects framework}

The Ozone Unit Macedonia has established an excellent cooperation with the United Nations Industrial Development Organization (UNIDO) as an implementing agency of the Montreal Protocol, and with the Multilateral Fund of the Montreal Protocol as a provider of funds to help developing countries comply with their obligations under the Protocol to phase out the use of ODS at an agreed schedule. As a result of their partnership, the Ozone Unit Macedonia implemented numerous projects in almost all economic sectors that use ODS (production of cooling devices, soft and solid foams, agriculture etc.). Some of the implemented project are: Elimination of CFC-11/12 in the refrigerate factory "Frinko"-Bitola ${ }^{18}$ (theirs replacement/substitution with HFC); Elimination of CFC-11 in the production of soft foams in "Sileks"Kratovo $^{19}$ (theirs replacement/substitution with $\mathrm{CO}_{2}$ ); Elimination of CFC-11 in the production of solid polyurethane (PU) sandwich panels in "Sileks" Kratovo ${ }^{20}$ (theirs replacement/substitution with HCFC-141b); Project for replacement of methyl bromide in agriculture ${ }^{21}$ and others.

In addition to this, for customemployees and maintainers (repairers) of cooling devices, the Ozone Unit Macedonia organized training for cooling devices appropriate management, establishing and upgrading the system for collecting and recycling the refrigerator's fluids and other. ${ }^{22}$ This training was in the frame of the Plan for managing cooling resources and devices $\left(\mathrm{RMP}^{23}\right)$ and the

\footnotetext{
18104 metric tons eliminated.

${ }^{19} 76$ metric tons eliminated.

${ }^{20} 280$ metric tons eliminated.

${ }^{21} 45,4$ metric tons eliminated.

${ }^{22}$ Plan for elimination of HCFC substances in

Republic of Macedonia, 2009, Ministry of environment and physical planning, Republic of Macedonia, June 2009.

${ }^{23}$ RMP, Refrigerant Management Plan (Plan for managing with the cooling resources and devices). 45 metric tons eliminated.
}

Plan for final elimination of $\mathrm{CFCs}$ $\left(\mathrm{TPMP}^{24}\right)$.

In the past period, big attention was paid on public awareness rising regarding the necessity of decreasing the ODS consumption. All generations, including the kids from the kindergartens and professionals that work with ODS, are included in the national action for protection of the ozone layer. For that purpose, there are a big number of thematically prepared brochures, documentaries, pamphlets and other, which brings the problem of ozone layer depletion closer to the public. This effort gives the citizens opportunity to get actively involved in the national campaign for ODS elimination.

In the past period, three regional workshops with representatives of all countries in the region were organized.

In June 2011, a two-day workshop for refrigerants and devices containing CFCs management was organized. At the workshop, 20 professors from 11 technical high schools in Macedonia were trained for implementation of the program for "Elimination of HCFC refrigerants". Training of 10 professors from the technical high school "Gjorgji Naumov" from Bitola was also organized.

In order to facilitate the educational activities, a Manual for elimination of HCFC refrigerants and a Methodology for conduction training on HCFC refrigerants elimination, were prepared.

\section{Analysis, findings and discussion}

Special attention was paid on the process of collecting and recycling the refrigerants (including also HCFC's). In that respect, the maintainers of cooling devices got the equipment for free. At the same time, three recycling centers in Macedonia were established. As one can see, collected amounts of CFC's in the

\footnotetext{
${ }^{24}$ TPMP, Terminal Phase-out Management Plan (Plan for final elimination of CFC). 43,3 metric tons eliminated.
} 
period from May 2001 to 2008 inclusive, vary between 1.100 and 1.900 kilograms, and in 2009 and 2010 the amounts are reduced approximately three times and the numbers are: 502 kilograms in 2009 and 589 kilograms in 2010.

Table 1. Collected and recycled refrigerants in the period $2001-2010$, in kilograms

\begin{tabular}{|c|c|c|c|c|c|c|c|}
\hline & C & $\mathbf{L}$ & $\mathbf{E}$ & $\mathbf{T}$ & D & RECYCLED & WASTE \\
\hline Year & CFCs & HCFC-22 & HFCs & Mixtures & Total & & \\
\hline May 2001- December 2002 & 1546,5 & 1203,4 & 512,0 & 22,0 & 3283,9 & 2820,9 & 463,0 \\
\hline 2003 & 1188,1 & 1183,0 & 173,0 & 22,0 & 2566,1 & 2466,1 & 100,0 \\
\hline 2004 & 1946,0 & 2598,4 & 2542,5 & 238,5 & 7325,4 & 7101,6 & 223,8 \\
\hline 2005 & 1775,7 & 2741,5 & 2863,0 & 254,5 & 7634,7 & 7191,5 & 4432 \\
\hline 2006 & 1823,8 & 1698,6 & 777,6 & 1400,3 & 5700,3 & 5452,8 & 247,5 \\
\hline 2007 & 1873,0 & 2226,0 & 1745,0 & 2332,0 & 8176,0 & 8089,0 & 87,0 \\
\hline 2008 & 1341,4 & 4495,8 & 2110,4 & 2847,0 & 10794,6 & 10407,8 & 386,8 \\
\hline 2009 & 502,0 & 2692,0 & 880,0 & 1983,0 & 6057,0 & 6057,0 & 352,8 \\
\hline 2010 & 589,2 & 2877,0 & 1350,0 & 3590,0 & 8406,2 & 8406,2 & 256,5 \\
\hline Total & 12585,7 & 21715,7 & 12953,5 & 12689,3 & 59944,2 & 57992,9 & 2560,3 \\
\hline
\end{tabular}

Regarding the collected amounts of HCFC-22, the biggest amount is collected in 2008 - almost 4.496 kilograms. The smallest one was in $2003-1.183$ kilograms.

Regarding the hydro-fluorocarbons (HFC), the smallest amount was collected in 2003 - 173 kilograms, and the biggest amount in 2005 - 2863 kilograms. In the following years, amounts vary from 1.350 to 2.542 kilograms.

Collecting mixtures in the first three years (2001-2003) is minimal and it increases every following year in order to reach the amount of 3.590 kilograms in 2010.

Generally, the smallest amounts are recycled in the first three years (2.466 and 2.820 kilograms). After that, the amount increases more than three times in the following three years (2004-2006), four times in 2007 and reaches the maximum in 2008 - 10.407 kilograms.

Regarding the eliminated substances, the situation is shown in Table 2. So, Table 2 shows that CFC-11 was fastest eliminated. In the first three years (1995-1997) the biggest amount of total of $1.311,4$ tons was eliminated. Fifteen tons were eliminated in 1998, and the rest of approximately 16 tons were eliminated in 1999 and 2000.

Regarding CFC-12, the amounts in the period 1995-1999 varies between 72 tons (in 1995) and 183 tons (in 1999). In the period 2000-2003, the amounts goes from 39,5 tons (in 2001) to 44,5 tons (in 2003). In the next three years $(2004,2005$, 2006) other 27,1 tons were eliminated. The elimination is completed in 2007.

The only amounts of 0,02 tons of CFC-113 are eliminated in 2000, and the amount of 6 tons of CFC-114 was eliminated in 1995. In one year (1997) it has been eliminated the amount of 3,8 tons Halon-1211, and in 1999 it has been eliminated 1,4 tons of CFC-111.

The elimination of CFC-115 started in 1999 when 0,02 tons were eliminated, and ended in 2004 with the elimination of 0,5 tons.

The entire amount of 92,5 tons of Halon-1301 has been eliminated in the period of three years $(1995,1996,1997)$.

Biggest amount of $\mathrm{CCl} 4$ has been eliminated in 1996 (almost 4,5 tons). In the next six years (including 2006), 2,8 tons have been eliminated.

Biggest amount of HCFC-22 has been eliminated in 2001 (10,4 tons) and smallest in 2010 (1,3 tons).

HCFC-141b has been eliminated by 2002 inclusive.

Methyl bromide has been eliminated in the period from 1996 to 2002. 
Table 2. Eliminated ODS in the period 1995 - 2010, annually in tons

\begin{tabular}{|c|c|c|c|c|c|c|c|c|c|c|c|c|c|c|c|c|}
\hline Substance & '95 & ‘96 & '97 & '98 & '99 & ‘00 & '01 & '02 & '03 & '04 & ‘ 05 & '06 & '07 & ‘ 08 & ‘09 & $' 10$ \\
\hline CFC-11 & 480,0 & 413,0 & 418,4 & 15,0 & 8,8 & 7,1 & & & & & & & & & & \\
\hline CFC-12 & 72,0 & 101,0 & 69,0 & 77,8 & 183,1 & 39,6 & 39,5 & 34,1 & 44,5 & 8,3 & 11,8 & 7,0 & & & & \\
\hline CFC-113 & & & & & & 0,02 & & & & & & & & & & \\
\hline CFC-114 & 6,0 & & & & & & & & & & & & & & & \\
\hline CFC-115 & & & & & 0,02 & 2,72 & 7,1 & 0,04 & 4,8 & 0,5 & & & & & & \\
\hline $\begin{array}{l}\text { Halon- } \\
1211\end{array}$ & & & 3,8 & & & & & & & & & & & & & \\
\hline $\begin{array}{l}\text { Halon- } \\
1301 \\
\end{array}$ & 30,0 & 30,0 & 32,4 & & & & & & & & & & & & & \\
\hline CFC-111 & & & & & 1,4 & & & & & & & & & & & \\
\hline $\mathrm{CCl} 4$ & & 4,4 & 0,02 & 0,1 & 0,1 & 0,04 & & 0,01 & & & 0,01 & & & & & \\
\hline HCFC-22 & 1,5 & 2,3 & 1,8 & 1,2 & 1,1 & 4,9 & 10,4 & 3,8 & 6,0 & 4,7 & 1,9 & 2,3 & 1,2 & 2,0 & 2,2 & 1,3 \\
\hline $\begin{array}{l}\text { HCFC- } \\
141 \mathrm{~b}\end{array}$ & & 0,1 & & 2,3 & 0,1 & 0,1 & & 0,1 & & & & & & & 1,7 & \\
\hline $\begin{array}{l}\text { Methyl } \\
\text { bromide }\end{array}$ & & 12,0 & 12,0 & 12,9 & 27,0 & 23,4 & 19,8 & 5,3 & & & & & & & & \\
\hline Total & 589,5 & $\begin{array}{l}562,8 \\
\end{array}$ & 537,6 & 109,3 & 221,8 & 77,8 & 77,0 & 43,4 & 55,3 & 13,5 & 13,7 & 9,3 & 1,2 & 2,0 & 3,9 & 1,3 \\
\hline
\end{tabular}

Generally, the biggest amounts of eliminated ozone layer substances are in the first three years (1995-1997) and they go from 589 to 537 tons. They rapidly go down in 1998 (109 tons), increasing to 221 tons in 1999. After 2000 there's a drastic fall of 77,8 tons, over 55 tons in 2003 to approximately 13 tons in 2004 and 2005. From 2006, the amounts are less than 10 tons, and in 2010 is only 1,3 tons (HCFC22).

Realized projects by the Ozone Unit Macedonia resulted with elimination of more than $98 \%$ of the consumption of the ozone layer depleting substances in Macedonia.

\section{Concluding remarks}

Fulfilling the obligations arise of Montreal Protocol ratification means systemic approach and cover drafting a new legislation and amending the existing one, realizing activities for public awareness rising, organizing trainings for stakeholders, implementing activities for reduction and elimination of the ozone depleting substances, etc., which was not an easy task for Macedonia.

Yet, the survey done on the secondary legislation regulating this chemicals, leads to the conclusion that it enables and accelerates their limitation, control, evidence and phase out.

In order to raise the awareness of the ODS problem, thematic brochures, documentaries, and other promotional materials were prepared.

Furthermore, as an effect of the excellent cooperation established with the international organizations, and relevant stakeholders involvement in all phases of ODS management, the research done shows that many projects were implemented in the period of thirteen years (1997-2010) resulting with the elimination of the nearly entire amount of ODS, except HCFC's. More than $98 \%$ of the ozone depleting chemicals was eliminated of theirs consumption in Macedonia.

This makes Macedonia "success story" regarding the fulfillment of the obligations under the Montreal Protocol.

\section{References}

1. Diener, E., and Suh, E., Measuring quality of life: economic, social, and subjective indicators, Social Indicators Research 40: 189-216, Kluwer Academic Publishers, 1997.

2. Directive for interdiction of import of used fridges, refrigerators and other devices for cooling and freezing and import of ozone layer depleting substances. "Official Gazette of Republic of Macedonia" n. 87/2006.

3. Directive for interdiction of production and ozone layer depleting substances trade, as well 
as production and trade of products containing ozone layer depleting substances. "Official Gazette of Republic of Macedonia” n. 92/2010.

4. Directive for interdiction of import and export of products containing HCFC. "Official Gazette of Republic of Macedonia” n. 92/2010.

5. Directive for limiting import of ozone layer depleting substances "Official Gazette of Republic of Macedonia" n. 92/2010.

6. Directive for limitation of import of airconditioning devices containing hydrochlorofluorocarbons. "Official Gazette of Republic of Macedonia" n. 92/2010.

7. European Environment Agency, Environmental Signals 2000, Environmental Assessment Report No. 6, 2000.

8. HCFC Management Phase out Plan, Ministry of Environment and Physical Planning Republic of Macedonia. June 2009.

9. Molina M. J and Rowland S., Stratospheric Sink for Chloro-fluoro-methanes: chlorine Atom-Catalysed Destruction of Ozone (Nature Vol. 249, 28 June 1974).

10. Prescott-Allen, R., 2001. The Wellbeing of Nations: A Country-by-country Index of Quality of Life and the Environment, Washington, D.C.: Island Press, available at: http://www.eoearth.org/ article/Indicators_of_sustainable_development\#gen 0 .

11. Regulation (EC) No $1005 / 2009$ of the European Parliament and of the Council of 16 September 2009 on substances that deplete the ozone layer. Official Journal of the European
Union L 286/1 I, 9.31.10.2009, available at http://www.minenv.gr/4/41/4121/Reg1005_2009EN.pdf (accessed October 2012).

12. The Montreal Protocol on Substances that Deplete the Ozone Layer (Secretariat for The Vienna Convention for the Protection of the Ozone Layer \& The Montreal Protocol on Substances that Deplete the Ozone Layer, 2000), ISBN: 92-8071888, available at http://ozone. unep.org/pdfs/Montreal-Protocol 2000.pdf, 25-30 (accessed October 2012).

13. Ozone Unit Macedonia, www.ozoneunit.gov.mk/eng/ozone.html (accessed November 2012).

14. Ministry of Environment and Physical Planning, Government of Republic of Macedonia, www.moepp. gov.mk/defaulten.asp?ItemID=87678FCBEF640149A101D85A6 BECA217 (accessed 10 October 2012).

15. United Nations Economic and Social Council, Protection of the Atmosphere, Addendum, Report of the Secretary-General, Commission on Sustainable Development, Fourth Session, 18 April-3 May, 1996.

16. United Nations Department of Economic and Social Affairs, UN CSD Theme Framework and Indicators of Sustainability.

17. United Nations, 1994. Earth Summit, Agenda 21, the United Nations Programme of Action from Rio, New York: United Nations (sales no. E.93.I.11). ISBN: 9211005094, available at: http://www.eoearth.org/article/Indicators_of_sustai nable_development\#gen0 (accessed October 2012). 